\title{
Hydropolis: reinterpreting the polis in water politics
}

\section{Article}

\author{
Accepted Version
}

Creative Commons: Attribution-Noncommercial-No Derivative Works 4.0

Menga, F. (2017) Hydropolis: reinterpreting the polis in water politics. Political Geography, 60 (September). pp. 100-109. ISSN 0962-6298 doi: https://doi.org/10.1016/j.polgeo.2017.05.002 Available at https://centaur.reading.ac.uk/72303/

It is advisable to refer to the publisher's version if you intend to cite from the work. See Guidance on citing.

To link to this article DOI: http://dx.doi.org/10.1016/j.polgeo.2017.05.002

All outputs in CentAUR are protected by Intellectual Property Rights law, including copyright law. Copyright and IPR is retained by the creators or other copyright holders. Terms and conditions for use of this material are defined in the End User Agreement.

\section{www.reading.ac.uk/centaur}

\section{CentAUR}

Central Archive at the University of Reading

Reading's research outputs online 


\title{
Hydropolis: reinterpreting the polis in water politics
}

\author{
Filippo Menga \\ Department of Geography and Environmental Science, University of Reading, United \\ Kingdom
}

Email: filippomenga@gmail.com
This is an Accepted Manuscript of an article published by Elsevier in Political Geography, Volume 60, pages 100-109, on September 2017, available online: https://authors.elsevier.com/a/1V17g3Qu6uG3nE [Article DOI 10.1016/j.polgeo.2017.05.002].

\begin{abstract}
The construction of a large dam is often a contested and controversial matter. Delicate aspects related to the dam construction business such as the resettlement of peoples, environmental impact and financial costs, can trigger popular discontent and hinder the realisation of a particular project. By advancing the notion of the hydropolis, a reinterpretation of Hannah Arendt (1958) definition of the polis, this paper will explore how ruling elites can manipulate the public opinion to politically construct a large dam as a foreign policy matter. This, it will be argued, serves to conceal the negative consequences of a dam so that issues related to its social and environmental impact are removed from the national political debate. Specifically, the case of the Grand Ethiopian Renaissance Dam (GERD) in Ethiopia will be used to illustrate how a large dam can become a geopolitical object grounded on the friend/enemy distinction, in the context of the longstanding geopolitical tensions in the Nile River Basin.
\end{abstract}

$\underline{\text { Keywords: Critical geopolitics; Transboundary waters; Hannah Arendt; Ethiopia; Egypt; Polis }}$

\section{INTRODUCTION}

On March 25, 2015, fans were cheering as the players of Welayta Dicha (an Ethiopian Football Club based in Sodo) lifted the Grand Ethiopian Renaissance Dam (henceforth GERD) Cup, a national football tournament that they had recently won. Whilst the tournament's name might appear surprising to some, it is perhaps less so to those familiar with recent Ethiopian political developments. In 2011, when the Ethiopian government started the construction of the GERD - on paper the largest dam in Africa - it also launched a parallel campaign aimed at making of the dam a patriotic project symbolising the renaissance of the Ethiopian nation after the atrocities committed by the Derg ${ }^{1}$, a 
military junta that ruled the country from 1974 to 1987 . The campaign has arguably been successful (Menga, 2016b), and the Ethiopian leadership presented the dam as a foreign policy matter, targeting Ethiopian nationals regardless of national borders or federal boundaries.

The political discourse generated by the GERD offers a good platform to illustrate that, in line with a changing and globalised world with deepening time-space compression (Harvey, 1999), the space of appearance in hydropolitics has expanded to encompass political and administrative boundaries. By advancing the notion of the hydropolis, a reinterpretation of Hannah Arendt (1958) definition of the polis ${ }^{2}$, understood in philosophical terms as a metaphor for the space of political appearance, this article will explore how ruling elites deliberately construct a large dam as a foreign policy matter to deproblematise its environmental and societal consequences.

Through an implementation of the discursive practice of othering and the framing of an issue in antagonistic terms as a friend/enemy one, a ruling elite can remove a particular issue from the political debate pre-empting the arousal of dissent. This will be demonstrated through an application to recent developments in the Nile River Basin. With regards to the Ethiopian ruling elite, the paper will show that its geopolitical imagination of the polis, the hydropolis, is grounded on the friend/enemy distinction and on the consequent spatial assumption that politics takes place wherever the enemy and the friend are co-located.

In concrete terms, this practice is relevant to the Ethiopian ruling class for at least three reasons. First, and in line with the Latin metonymic panem et circenses (bread and circuses), framing a domestic issue as a foreign policy one can serve to distract public attention from other pressing matters. Delicate aspects related to the dam construction business such as the resettlement of peoples, environmental impact and financial costs, can be concealed by a rhetoric that overemphasizes a foreign policy success, which in the case of Ethiopia is that the GERD is being built in spite of the opposition coming from Egypt and, to a lesser extent, Sudan. Second, and consequently, the prestige stemming from this endeavour can help legitimate the ruling elite and bolster popular support. Indeed, even though Ethiopia is an authoritarian regime (Abbink \& Hagmann, 2013), the government needs the support of its people to ensure its survival. As Arendt (1958: 200) observed, power "springs up between men when they act together and vanishes the moment they disperse", and thus, power, just like hydroelectricity, cannot be stored for the future but needs to be constantly generated and renewed. Third, this can help attract the significant and wealthy Ethiopian diaspora abroad, who are crucial to the funding of the GERD's construction in their purchase of dam bonds.

Hence, this article serves two principal purposes. The first, and more general, is to reflect on politics and on how the space of appearance should be treated in critical hydropolitical studies. By doing so, it contributes to both literature on critical hydropolitics (Sneddon and Fox, 2006; Mustafa, 2007; Warner and Zeitoun, 2008; Harris and Alatout, 2010; Akhter, 2015; Hirsch, 2016), and critical geopolitics (Ó Tuathail \& Agnew, 1992; Agnew, 2003; 2016; Dalby and Toal, 2006; Ó Tuathail, 2010). The second, and more specific purpose, is to provide an account of how the Ethiopian ruling 
elite has managed to frame the GERD as a foreign policy matter so that issues related to its social and environmental impact nearly disappeared from the national political debate. To illustrate how territory and society can be socially and politically constructed, the research perspective informing this article is based on discourse analysis (Van Dijk, 2006), with a focus on the ruling political elite in Ethiopia and on their discourses around the GERD. As Müller (2008) eloquently illustrated, discourses (and if we are to transcend the structure/agency dualism, also practices) emerge as a central form of power in the constitution of geopolitical identities.

The sources used include both official and non-official documents. On the one hand, official documents include speeches and declarations delivered by high-level politicians at national and international summits, official statements and government documents. These documents were gathered through the following sources: the official websites of the Ethiopian Prime Minister, of the Ministry of Foreign Affairs and of the Ministry of Water Resources; archival research at the African Union Commission Library in Addis Ababa; the United Nations Bibliographic Information System; the official Facebook page of the Ethiopian Ministry of Foreign Affairs, the Ethiopian Mission to the European Union in Brussels and to the United Nations in New York, and of the Ethiopian Embassy in London; the monthly publication of the Ethiopian Embassy in London, Ethiopian News; the government-owned website grandmillenniumdam.net ${ }^{3}$ and the website meleszenawi.org.uk. On the other hand, non-official documents consist of news reports produced by the national tightly controlled media, which serve as the mouthpiece of the government. These sources, which were scrutinised using 'LexisNexis' and 'BBC Monitoring Africa - Political', include: the English translation of the Amharic transcripts of the evening news programme from the state-owned television channel EBC (Ethiopian Broadcasting Corporation) and from the Ethiopian Radio and Television Agency (ERTA); reports from the pro-Ethiopian government Walta Information Centre website; and the weekly newspaper The Reporter. The period analysed starts in January 2010, the year before the launch of the construction of the GERD, and ends in December 2015. Further data was collected through phone interviews carried out between January and July 2016 and field work in the Ethiopian capital Addis Ababa between May and June 2016. During this time, semi-structured interviews and informal conversations were conducted with representatives from both the Ethiopian and the expatriate community.

The rest of this paper is divided into four sections. The next section situates the paper at the intersection of the scholarship on critical geopolitics, critical hydropolitics and critical water geography, to then offer theoretical insights on the notion of the polis and of its reinterpretation, the hydropolis. The third section provides an overview of water politics in the Nile River Basin, while the fourth section connects the theory to the empirical to illustrate how the GERD was framed as a foreign policy matter by the Ethiopian ruling elite. The final section discusses how the findings of this paper can be applied to future research in the field of transboundary water relations. 


\section{ON WATER, POLITICS AND THE POLIS}

Before embarking upon a discussion on politics and the polis, it is necessary to position this article at the intersection of the scholarship on critical geopolitics, critical hydropolitics and critical water geography. In doing so this section will highlight how spatial and geographical constructions can influence foreign policy making and prepare the ground for our exploration of the political in water politics. Critical geopolitics can indeed be defined as the study of myriad geographical assumptions and schemas that influence the making of foreign policy and world politics (Agnew, 2016). As Agnew notes, "these assumptions and schemas are seen as socially constructed by particular people in different historical-geographical circumstances and as thereby providing the basis for geopolitical rationales to social and political purposes that are anything but simple reflections of a natural geopolitical order." (Agnew, 2016:19). The early work on critical geopolitics (Ó Tuathail \& Agnew, 1992) identified three categories involved in the production of these discursive assumptions and the consequent spatialization of international politics: i) the formal geopolitical reasoning of strategic thinkers and public intellectuals; ii) the practical geopolitical reasoning of politicians, statespersons, and journalists; and iii) the reasoning in contemporary popular culture. While these three categories are closely intertwined, Kuus (2010) observed that practical geopolitics offers a particularly effective analytical focus since it combines elements of formal geopolitical reasoning with societal elements and metaphors from popular culture. Through practical geopolitical reasoning, the intellectuals of statecraft - a notion that recalls Gramsci's (1975) idea of the organic intellectuals ${ }^{4}$ - designate a world that is populated by various subjects, representations and histories often centred on binary distinctions and narratives (Ó Tuathail \& Agnew, 1992). In this geopolitical imagination, discourses and ideological processes serve to construct the idea of the 'self', or the domestic, as juxtaposed to the 'other', which is often represented as a threat (Dalby, 1990). This discursive practice of othering (Gregory, 1994) can be for instance based on competing visualisations of global space (Agnew, 2003), or on temporal ideas of 'backwardness', such as the ones originating from colonial encounters and evident in the discursive practice of "Orientalism" (Said, 1979), or those stemming from a comparison with the self's own past (Said, 2000; Diez, 2010).

Critical geopolitics challenges the deterministic formulations on geopolitical rivalries and "the geographical reasoning used in the legitimizations of contemporary warfare" (Dalby, 2010: 288), thus offering an alternative and more nuanced reading on how the intellectuals of statecraft shape foreign policy. This view resonates with current debates on critical hydropolitics, a notion advanced by Sneddon and Fox (2006) to question the dominant dichotomous approach on inter-state cooperation and conflict in the transboundary waters literature. A critical hydropolitics implies an engagement of critical geopolitics with the natural and 'real world' (Sneddon and Fox 2006: 184), to go beyond the water wars scenario and the analytical aridity of the Malthusian and cornucopian approaches toward the management of transboundary water resources. In the context of transboundary river basins, it is thus acknowledged that the geographical position of a basin riparian is less of a determining factor 
than the use of power (Mirumachi, 2015), as such hegemonic relations and power asymmetries need to be considered to understand transboundary water politics (Zeitoun and Warner, 2006; Zeitoun et al., 2011, 2016; Menga, 2016a). As Menga and Mirumachi (2016: 375) observed, transboundary water relations are influenced by "discursive framings of the environment and social construction of goals of river basin development and cooperative arrangements for such".

While critical hydropolitical studies have explored the way actors construct geographical scales, especially in relation with the domestic-foreign polarity (Warner \& Zawahri, 2012; Warner, 2012; Menga, 2016b), it is critical water geography that excavated the discursive construction of rivers as complex sociotechnical processes (Akhter, 2015). Research has highlighted how ruling political elites can preserve social control and disseminate ideas of modernization through the realisation of hydraulic infrastructures such as dams, canals and irrigation channels (Swyngedouw; 1999; Kaika, 2006; Giglioli \& Swyngedouw 2008). The political constructions of scales can further our understanding of water politics (Biro, 2007; Alatout, 2008; Feitelson \& Fischendler, 2009). Swyngedouw (2004a) formulated the concepts of hydro-social territory and waterscape to explore how scales can be constructed by a national elite, becoming "arenas around which socio-spatial power choreographies are enacted and performed" (Swyngedouw, 2004b: 28). Water can shape social relations beyond the watershed scale (Budds \& Hinojosa, 2012), and scalar negotiations and constructions of water can play a central role in state-consolidation (Harris \& Alatout, 2010).

Thanks to the advancement of critical water studies, water is no longer seen as a merely technical issue. Water resources management is an inherently political process (Mollinga, 2008; Wegerich \& Warner, 2010), where transboundary watersheds become problemsheds (Allan, 2001) in which diverging narratives are socially and politically constructed (Norman et al., 2016). Through top-down means, river basins can be constructed as unique spatial entities where geopolitical objectives unfold (Sneddon \& Fox, 2016). If we accept that water issues are inexorably political issues (Swyngedouw, 2013), we also need to understand how contested and controversial hydraulic developments are constructed as geopolitical objects to remove them from the political debate. To explore how this process can take place in hydropolitics, we now need to turn our attention to some theoretical considerations on the space of appearance in politics.

As Norberto Bobbio succinctly defined it in Il dizionario di politica (Bobbio et al., 2004), politics is the activity of bringing together and defending our friends, and disaggregating and fighting our enemies. This binary definition based on the friend/enemy distinction is inspired by Carl Schmitt (2007: 26), who claimed that "the specific political distinction ... is that between friend and enemy" in the public sphere, with war (the polemos) being the most extreme form of this antagonism in an essentially dyadic view of politics (Bobbio, 1994). While defining politics and the 'political' remains an essentially controversial and contestable matter, the above perspective has two significant implications for the current study. The first is that politics involves a conflictual relationship between at least two groups (the friend and the enemy, the known and the unknown), while the second is that 
political interactions are based on perceptions and appearances. Furthermore, and inevitably, if we focus on appearances we are implying that there is a spatial dimension of politics, an arena where politics happen.

This arena within which politics is conducted, and from where the word politics in itself derives, is the polis, the ancient Greek word meaning 'city-state'. The meaning of the word polis, however, goes well beyond that of a mere city or of a state, and deserves to be further interrogated. As Elden (2000: 415) thoughtfully illustrated in his reading of Heidegger, we "could not use our understanding of the political to explain the $\pi$ ó $\lambda ı \varsigma$ [polis], but, as the political derives from the $\pi$ ó $\lambda \iota \varsigma$ [polis], we can use our understanding of $\pi$ ó $\lambda ı \varsigma$ [polis] to rethink the political". The polis therefore emerges as a site of being for the political, as a space of interaction between various groups.

This brings us closer to Arendt's understanding of the polis and of the space of appearance. It is in The Human Condition that Arendt (1958) introduced in detail her view of the world as a public stage, exploring how the political realm is constituted directly by human plurality. Arendt argued (1958: 198) that "the polis, properly speaking, is not the city-state in its physical location; it is the organization of the people as it arises out of acting and speaking together, and its true space lies between people living together for this purpose, no matter where they happen to be". Pericle's exhortation to the Athenians, "wherever you go, you will be a polis", is used by Arendt to explain that action and speech can create space almost anytime and everywhere. The space of appearance, Arendt adds (1958: 199), "comes into being wherever men are together in the manner of speech and action, and therefore predates and precedes all formal constitution of the public realm and the various forms of government, that is, the various forms in which the public realm can be organized".

Besides the recognition that actions and discourses can constitute a polis, what is important in Arendt's argument is her understanding of the world as a public stage, something that, as Tavani explained (2013: 467), allows us to reflect on its "phenomenal nature" and on the coincidence between being and appearing. As Arendt later clarified in On Revolution (2006: 98), "in politics, more than anywhere else, we have no possibility of distinguishing, between being and appearance. In the realm of human affairs, being and appearance are indeed one and the same." Therefore, appearance - which in this case we should interpret as the rhetorical discursive projection of a specific political imagination - becomes the constitutive element of reality and of the polis. At any moment in time, adds Zerilli (2005: 20), a physical space can be transformed into a political one, even though this space of appearance exists "only so long as people are engaged in speech and action". A transient and mutable nature of the space of appearance thus arises, from which we can infer that its spatial extent also varies as time goes by.

One important point needs to be made to appreciate the mechanism through which a ruling elite can frustrate political action by changing the appearance of something. While, on the one hand, the polis can be viewed as the central space of political encounter where interactions between various groups take place, on the other hand, it is also the arena within which politics is conducted, and 
where, therefore, speech and action can also be manipulated. The polis can thus, in turn, be predated by those in power to foreclose political encounter, and as a result, politics frustrates the political, with the latter being understood as "the space for the arrangement of egalitarian public encounter of heterogeneous groups and individuals" (Swyngedouw, 2014: 123). Under this perspective, the original Arendtian normative argument that the polis has the potential for horizontally advancing common will formation, is corrupted by means of a political and ideological construction that hinders political encounter and confrontation.

For the purpose of this work, the term hydropolis denotes the application of the notion of the polis to the domain of water politics and hydraulic development. Rather than providing a normative connotation, the 'hydro' qualifier merely has the etymological role of prompting a discussion on the necessity to study politics and the political in the field of hydropolitics and critical geopolitics. This serves to illustrate that just like the polis can be twisted, so does the hydropolis, which in this case emerges as a manipulated political space where a particular issue is removed from the public debate to pre-empt the opportunity for internal dissent to arise.

A reinterpretation of the polis has at least two main implications for the study of water politics. First, if we consider the polis as the site of being for the political and as an abstract entity whose space lies between groups being together, we can deduce that politics happens, potentially, in any place where friends or enemies are located, regardless of state boundaries. In line with the long-term tendency identified by Agnew (2003), the spatiality of politics in the contemporary world seems to be based on the model of an integrated world society where social groupings are the main actors. However, rather than talking about a 'global polis', as suggested by Neufeld (1995), it is more appropriate to refer to a 'glocal polis', after Swyngedouw's (2004b) notion of glocalization used to indicate the simultaneous local and global reach of political activities. Under this framing, the hydropolis emerges as a seemingly borderless arena of political encounter which is nevertheless anchored to local, and at times very material, elements. Let us take, for example, the issue of hydraulic development. A physical object such as a large hydroelectric dam occupies a well-defined geographical space and has a number of manifest consequences at various levels. For local populations, these will include landscape changes, loss of cultural heritage sites, and resettlement policies. At the country level, a large dam will have an impact on state budgets, irrigated land, flood control, and electricity generation. At the wider river basin level, a large dam will influence the amount of water flowing to other basin riparians, and consequently will have strategic and geopolitical consequences for the parties involved. In our understanding of the hydropolis, ruling politicians will transform the physical space occupied by a large dam into a political one whose spatial extent cannot be demarcated in any other way other than by that defined by their space of appearance. A ruling elite will set the hydropolis wherever the recipients of its speeches and actions are located, on the basis of their political imaginations and assumptions. 
The second implication lies in the fact that the condition of plurality associated to the polis, its same existence, originates from and is preserved by the use of power, as without power the space of appearance will rapidly fade away (Arendt, 1958). Arendt's idea that power only exists as a potential that needs to be constantly actualised allows us to bring to the surface important matters such as the contested nature of the nation (Harris and Alatout, 2010), and the processes behind the political construction of scale. Research has indeed shown that governments can adopt a nationalistic rhetoric in which the construction of internationally contested hydraulic infrastructures becomes a way to both assert power over an antagonist neighbour, and legitimise and consolidate their grip on power (Worster, 1985; Mitchell, 2002; Menga, 2015). The friend/enemy distinction thus becomes a constituting element of the hydropolis, defining the nature of the space of appearance. Arendt therefore encounters Schmitt, and while the compatibility between the two is arguably not as evident as Kalivas (2008) suggested (for a critique refer to Ackerman, 2011), Arendt (1996) did explore the distinction between self and neighbour and the ways in which, in our "concrete worldly existence" (Arendt: 1996: 94), we can give to our neighbour a meaning of friend or enemy.

In more practical terms, the notion of the hydropolis lets us appreciate the processes through which ruling elites can deproblematise the environmental and societal consequences that come with the construction of a large hydraulic infrastructure. The shift from the local to the global is part of a move aimed at stretching the space of appearance, so that a domestic issue becomes a foreign policy one and serves as a distraction from other matters. In the case of Ethiopia and the GERD, this study will show how the Ethiopian leadership has drawn its space of political appearance along the lines of an imagined Ethiopian nation, with a conception of the polis grounded on the friend/enemy distinction epitomised by their rivalry with Egypt. The social groupings acting in this public stage reflect the hydropolitical tensions that marked the Nile River Basin during the last two decades. The spatial extent of the hydropolis might however change in the future as new power dynamics unfold, and I will return to this point in the penultimate section of this paper.

To contextualise the upcoming discussion, the next section provides a brief overview of hydropolitics in the Nile River Basin, illustrating the main characteristics of the GERD along with its political and environmental impact on Ethiopia and its neighbours.

\section{WATER POLITICS IN THE NILE RIVER BASIN}

And I think that their account of the country was true. For even if a man has not heard it before, he can readily see, if he has sense, that that Egypt to which the Greeks sail is land deposited for the Egyptians, the river's gift-not only the lower country, but even the land as far as three days' voyage above the lake, which is of the same nature as the other, although the priests did not say this, too.

Herodotus, 1920, 2.5.1 
These are the words that Herodotus used in the $5^{\text {th }}$ century B.C. to describe the importance of the Nile River for Egypt. The enunciation "Egypt is the gift of the Nile" has actually become one of the general premises adopted by analysts, scholars, and practitioners to open their writings on water politics in the Nile River Basin. And Egypt, on its account, has indeed based its demands over the Nile on the assumption that the country has natural and historical rights to its waters (Cascao, 2009). However, besides being a gift for Egypt, the Nile is also the world's longest river, and eleven countries share the water of its two main tributaries, the White Nile and the Blue Nile: Burundi, DR Congo, Egypt, Eritrea, Ethiopia, Kenya, Rwanda, South Sudan, The Sudan, Tanzania and Uganda. Among them, Egypt is both the most downstream and the most dependent on the river, and without its water the country would be a desert. In 1959, Egypt and Sudan signed the Agreement for the Full Utilisation of the Nile Waters, which allocated 55.5 Billion Cubic Meters (BCM) of water to Egypt and 18.5 BCM to Sudan, and thus institutionalised the former's historical demands over the Nile. This colonial-era agreement (for a comprehensive account of the politics of the Nile River Basin in the colonial age refer to Tvedt, 2004), which is not recognised by the other riparians who had been, de facto, excluded from regional water politics, also led to the construction of the grandiose Aswan High Dam in the 1960s, which gave Egypt control of a large part of the flow of the Nile and became the country's “centerepiece of postwar nation making" (Mitchell 2002, 45).

Egypt has dominated hydropolitics in the region, and a large part of the scholarship on the Nile has focused on Egypt and on its role in the basin (among others Smith \& AI-Rawahy, 1990; Beinin \& Lockman, 1998: Kendie, 1999; Vasunia, 2001; Mitchell, 2002). Things have however changed during the last decade, and the Egyptian hegemony over the Nile is being challenged by the other basin riparians, as if they were retrospectively asking Herodotus "whose gift is the Nile anyway?" (Ibrahim, 2010: 284). In 1999, the establishment of the Nile Basin Initiative (NBI), an intergovernmental partnership between the Nile Basin countries supported by the World Bank (WB), seemed to herald a new era of cooperation in the basin, even though its effectiveness has been questioned (Swain, 2002). The NBI has nevertheless served as a platform to negotiate the Nile Basin Cooperative Framework Agreement (CFA) (Mekonnen, 2010), a legal instrument through which six of the Nile upper riparians (Ethiopia, Tanzania, Uganda, Rwanda, Kenya and Burundi) are claiming their rights over the waters of the Nile (Ibrahim, 2010). The CFA has crystallised tensions between the upper riparians and the lower ones, Egypt and Sudan, which are worried that this will lead to the construction of more dams upstream and a consequent reduction in their water flow (Salman, 2013). Indeed, in the past Egypt threatened to go to war if Ethiopia tried to build dams on the Blue Nile. In 1979, the Egyptian President Anwar Sadat famously said that "the only matter that could take Egypt to war again is water" (quoted in Starr, 1991:19), adding one year later that "If Ethiopia takes any action to block our right to the Nile water, there will be no alternative for us but to use force" (quoted in Krishna, 1988). 
As Fred Pearce (2015) observed, this threat worked until 2011 but then, when Egypt was going through the turbulences of the Arab Spring, Ethiopia seized the moment and, without warning, began building the GERD on the Blue Nile. The launch of the GERD represents, according to many (among others Hammond, 2013; Chen \& Swain, 2014; Yihdego et al., 2016), a turning point in water politics in the Nile River Basin, as it brings a change to the balance of power between its two most populous countries. It also led scholars and analysts to identify Ethiopia as the new emerging hegemon in Africa (Gebreluel, 2014: Verhoeven, 2015), and the journal Water International (2016) dedicated a special issue exclusively to the GERD. But what is it that makes the GERD so important? Why, for instance, the construction of the large Merowe Dam on the Blue Nile in Sudan in the 2000s did not get the same level of attention? Significantly, the GERD will be the first large dam on the Blue Nile to be built outside of Egypt and Sudan. It will also be the largest dam in Africa, measuring 1,800 $\mathrm{m}$ in length, $175 \mathrm{~m}$ in height and with a reservoir that will be able to store 10 Million Cubic Meters (MCM) of water (Salini Impregilo, n.d.). The dam is primarily designed to generate hydropower, and upon its completion, tentatively foreseen for 2018, it will generate 6,000 MW (Zhang et al., 2016), which will allow Ethiopia to quadruple its current installed electricity generating capacity of 2,000 MW, and to sell surplus electricity to its neighbours through the planned Eastern Africa Electricity Highway Project. The GERD thus acquired a symbolic value as a project that will help eradicate poverty in Ethiopia (Pearce, 2015), a country that in the 2000s had one of the highest poverty rates in the world (World Bank Group, 2015). 


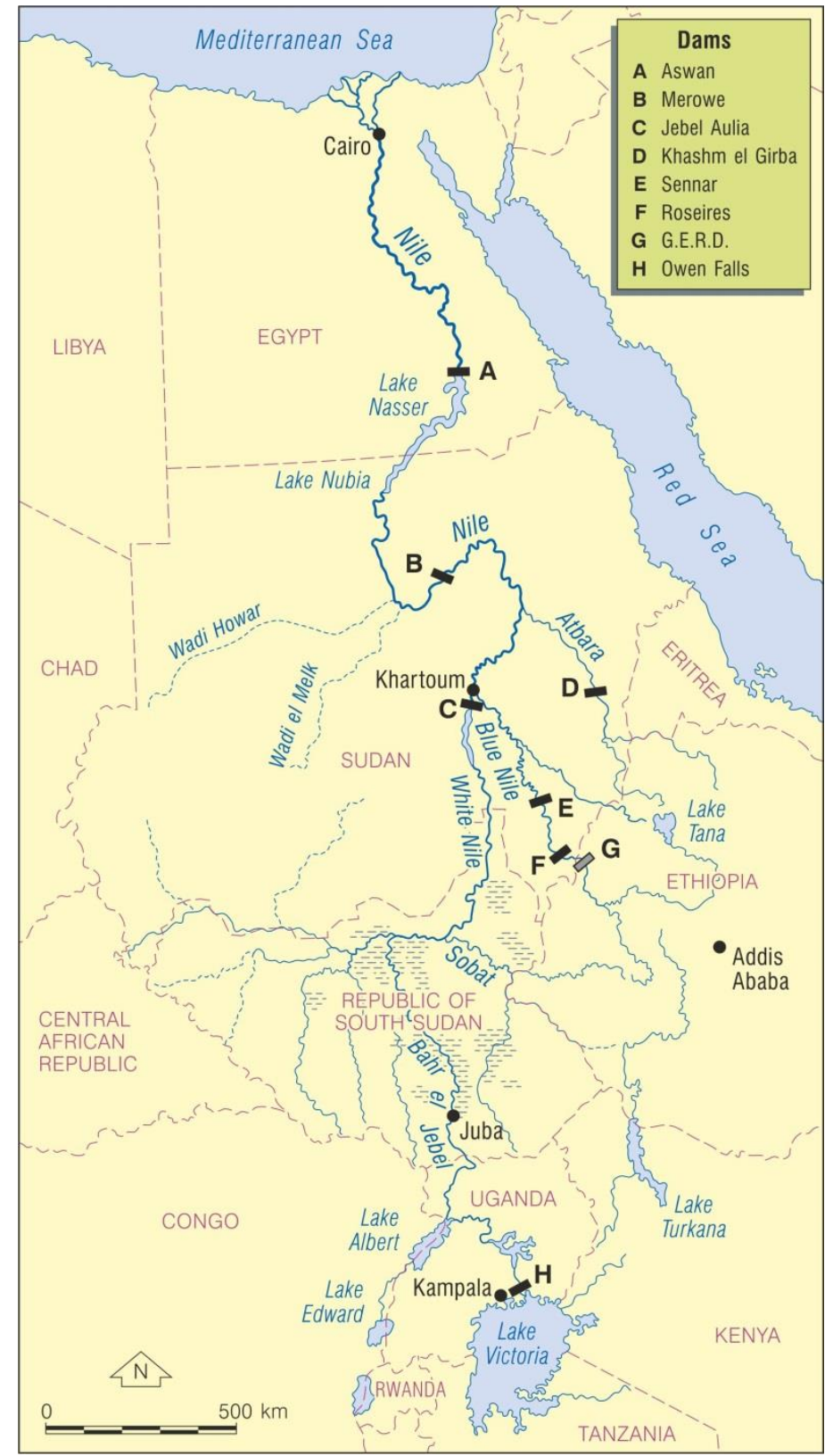

Figure 1: The Nile River Basin and its main dams in 2016. Source: Nick Scarle, Cartographic Unit, University of Manchester.

Nevertheless, the GERD is also extremely controversial, as it is often the case with this kind of projects which inevitably have an impact at both the domestic and the international level (Menga, 2016b). With a staggering cost estimated at US\$5 billion (Hammond, 2013), the project impacts heavily on Ethiopia's national budget, which in 2011/2012 amounted to US\$8 billion (Reuters, 2011). According to Flyvbjerg and Ansar (2014), the GERD will more likely cost US\$10 billion, and rather than "helping Ethiopia grow, the dam could drown the country's fragile economy in debt". The Ethiopian government has decided to self-finance the project through its own resources and the sale of dam bonds, with citizens being reportedly pressured to invest on the GERD (Brookings, 2013). According to a 2013 report prepared by an International Panel of Experts (IPoE, 2013), the GERD 
might also negatively impact on biodiversity and fisheries in both Ethiopia and Sudan, even though the studies carried out so far seem superficial and incomplete (International Rivers, 2014). The dam will also flood nearly 1,700 square kilometers of forest, leading to the forced resettlement of approximately 20,000 people, irreversible changes in the landscape, and the loss of cultural sites (International Rivers, 2014). This is an important point, as during the last few years resettlement policies in Ethiopia have sparked controversies. The construction of the Gilgel Gibe III Dam on the Omo River has for instance divided the local opinion, triggering debates on legitimate governance and raising harsh domestic criticisms voiced primarily through the Internet (Abbink, 2012). More recently, demonstrators took to the streets (four hundred of them were reportedly killed by Ethiopian security forces) in the Ethiopian region of Oromiya, to protest against the Integrated Addis Ababa Master Plan, which would displace thousands of Oromo farmers (BBC News, 2016). Furthermore, at the international level, the fact that the dam is under construction does not mean that Egypt is no longer opposing the project. In 2013, in the midst of an emblematic and rather embarrassing moment, Egyptian politicians were inadvertently caught on camera while discussing possible ways to sabotage the GERD, which included using the intelligence service to destroy it if all else failed (Tigrai Online, 2013).

In spite of its political authoritarianism, the government's ambitious attempt to make Ethiopia a developmental state (Di Nunzio, 2015) forces it to seek legitimation and get popular support to maintain social order. As stated by a project officer working in the development sector in Addis Ababa, "Ethiopia knows that it needs donors, and to keep them [the donors] coming, the country needs to show that they can offer a stable business environment and that they can ensure a capillary control of the territory." Popular unrest, therefore, needs to be avoided, especially when it comes to a flagship project like the GERD. Furthermore, dams tend to be surrounded by a rhetorical discourse that emphasises their contribution to a prosperous future and to the realisation of national goals while nurturing development and progress (Menga, 2015). This resonates well with the developmental discourse and broader ideas of state- and nation-building, while also meshing with the friend/enemy distinction, as it implies that those who support the dam are patriots, but those who don't, are enemies of the nation.

In a setting deeply marked by the historical rivalry between Ethiopia and Egypt, the GERD emerged as a geopolitical tool used by the Ethiopian government to assert its power and get legitimation. As the Egyptian scholar Rawia Tawfik (2016: 578) argued, the GERD "is presented as a sign of Ethiopia's determinism to redress historical injustices in the utilization of the Nile's water resources and exercise its right to use these resources, even if it would bear a heavy financial and political cost". The Ethiopian government's tight control of the media and of the Internet (Gagliardone, 2014) allowed it to undisputedly frame the GERD as a foreign policy issue, deproblematising its environmental and societal consequences, as the next section illustrates. 


\section{THE ETHIOPIAN HYDROPOLIS}

To understand the articulation of the geopolitical assumptions that led to the creation of the Ethiopian hydropolis, two factors need to be taken into consideration in addition to the historical hydropolitical rivalry with Egypt. The first is the large Ethiopian diaspora, which can be estimated to total nearly a million people and which continues to grow globally. The diaspora exercises a significant economic and political influence on the homeland (Lyons et al., 2007; Chacko \& Gebre, 2013), and is often called to financially contribute to the realisation of the GERD. The second are the challenges posed by ethnic federalism and a multi-ethnic society, which are being addressed by the Ethiopian government through the introduction of new idioms of nationhood such as the millennium ${ }^{5}$ rhetoric (Lentz, 2013; Orlowska, 2013). The GERD, whose initial name was the Millennium Dam, emerged as a symbol of Ethiopian nationalism (Abdelhady et al., 2015), and as an object that embodies the reawakening of the Ethiopian nation and its achievement of pride and success (Menga, 2016b). These elements are recurrent in the discourse maintained by the Ethiopian leadership, which made a shift from the local to the global in its imaginations and assumptions of the GERD. In line with the friend/enemy distinction, the recipients of its speeches and actions are located both within and outside the Ethiopian territory. The 'friend', in this particular narrative, is epitomised by the members of the Ethiopian nation, both in the diaspora and in the homeland, while the 'enemy' is personified by Egypt, to a minor extent Sudan, and in general by anyone opposing the construction of the dam.

This discourse is disseminated through a wide array of channels including national newspapers, TV and Radio outlets, the Internet, and social networking sites. The latter, in particular (see Pinkerton et al., 2011), have created new political spaces and new ways of reconfiguring the world and its social relations, consistently widening the space of appearance of the Ethiopian leadership. For example, in 2014, Ethiopia's Foreign Minister Dr Tedros Adhanom used his Ministry's official Facebook account to expound his opinion on the GERD and the Nile River more in general.

It is time to throw off the legacy of colonialism, which had bedevilled the exploitation of the Nile Basin for so long, and finally move into a new era of cooperation, with real and sustained development. ... In the past, we have been unable to use the considerable natural resources with which Ethiopia is endowed ... we are finally in a position to begin to exploit these resources properly, in the interests of national development. It is, of course, our right to do so in a manner that is acceptable to international norms and standards. ... A significant part of the problem has been that much of the comment [on the GERD from Egypt] is based on inaccurate claims and allegations. Indeed, Ethiopia has repeatedly gone above and beyond "the call of duty" in trying to assuage Egyptian concerns and to reach consensus over a more equitable allocation of the use of the Nile waters. 
Adhanom, 2014

This statement captures some of the key elements of the rhetoric surrounding the dam. Adhanom portrays the GERD as a tool to assert national interests and Ethiopia's rights over the Nile. Egypt is an important part of this narrative, and is denoted as a somehow capricious part which continues to hold a biased position in spite of the efforts made by Ethiopia to accommodate the situation.

Most of the assumptions and representations of the GERD maintained by the Ethiopian elite stem from the ideas and words of Meles Zenawi, a charismatic politician who was the Prime Minister of Ethiopia from 1995 until his death in 2012. Zenawi, who was defined by an Ethiopian diplomat as the mastermind behind the GERD (Jima, 2016), has indeed been instrumental in the genesis of the GERD both as a project and as a foreign policy matter. Already in 1998 Zenawi advanced the idea of building two large dams on the Nile, and while doing so he made numerous references to Egypt and its negative influence on the Nile, showing how his spatial imagination of the Nile was essentially based on the distinction between Ethiopia and Egypt (BBC, 1998). During the ceremony for the launch of the GERD, Zenawi accused Egypt of making "attempts to undercut Ethiopia's efforts to secure funding to cover the cost of the project" (Zenawi, 2011). Soon after that, Zenawi addressed the Ethiopian Parliament on the matter, spending words of praise for Sudan's cooperative approach, and blaming once more Egypt for its efforts to hinder Ethiopia's dam projects.

When we make a scientific assessment, an Egyptian invasion on Ethiopia is very small, but we cannot say it is zero. So, we should not lose sleep because of this small threat, but we need to make appropriate preparations to forestall the said threat. The solution is to live by supporting each other. So, it means we need to build our defence capability to ward off the said threat.

Zenawi, 2011

Zenawi clearly singled out Egypt as Ethiopia's main threat and antagonist for the country, in one of the rare cases in which the tone used by the Ethiopian leadership seems securitised. However, rather than on securitisation (which implies the discursive construction of "a plot that includes existential threat, point of no return, and a possible way out" [Buzan et al. 1998, 32-3]), the narrative adopted by the Ethiopian elite revolves around the discursive practice of othering and on a more subtle shift from the local to the global. Whether it is to clarify that "Ethiopia is not an enemy of the Egyptian people" (BBC, 2011a), or to explain to the Ethiopians citizens that the GERD is being built to eradicate poverty with benefit "not only for Ethiopia but also Egypt" (BBC, 2011b), Egypt is constantly brought into the discourse, even when this seems to be, arguably, unnecessary. 
Ethiopian media accounts of the GERD also provide an extensive and varied array of examples of these discursive constructions. Media in Ethiopia indeed serve as the mouthpiece of the government and tend to reproduce the official discourse maintained by the Ethiopian government. In particular, the news programme of the main Ethiopian TV channel, EBC, proved to be instrumental in the framing of the GERD as a foreign policy issue. In the period 2011-2015 EBC provided nearly weekly updates on the construction of the dam, and equal attention was given to the involvement and support shown by diaspora Ethiopians. EBC has broadcast numerous reports of Ethiopians abroad (living, among others, in the US, Canada, Germany, Dubai, the UK, Zambia, Kenya, and Somaliland) that show their patriotism by buying or pledging to buy government bonds in support of the GERD. Diaspora Ethiopians as well as Ethiopians from various parts of the country are also often seen touring the construction site of the GERD (BBC, 2012a; BBC, 2012b; BBC, 2013b), or cheering at the GERD Cup whenever it tours the country.

The reports from EBC TV tend, in general, to emphasise the international dimension of the dam also by underlining the interest and praise expressed by foreign head of states, diplomats, and scholars (BBC, 2014b; BBC, 2015a; BBC, 2015b). Ethiopian newspapers and news agencies also accurately reproduce the opinions expressed by the members of the Ethiopian government, and in the aftermath of the abovementioned leaked Egyptian recording, the Foreign Ministry Spokesman Dina Mufti urged them to play an even greater role in creating awareness on the benefits of the GERD for Egypt (BBC, 2013a). Mufti subsequently added that Egyptian rulers and politicians were carrying out an agenda aimed at discrediting the Ethiopian government, using the GERD as a pretext to divert attention from their domestic political troubles (BBC, 2013c). These "enemy provocations", as they were defined by a high-ranking official of the Ethiopian army (BBC, 2014a), are part of an "out of fashion water wars mentality", said a representative of a large Ethiopian environmental agency, and yet they seem to mirror the geopolitical assumptions on the Nile River maintained by the same Ethiopian elite.

Fekahmed Negash, a director at Ethiopia's Water, Irrigation and Energy Ministry, accused Egypt of carrying out a smear campaign on the dam. "Many of the communication materials they are using are full of wrong and false statements", he said, adding that "it is becoming clear now that Egyptian authorities are against the construction of the dam. Which implies that they are against the development of Ethiopia" (Walta, 2014). Besides Egypt, and as if it was essential to identify an enemy, the Embassy of Ethiopia in London observed that the current hydroelectric renaissance will help Ethiopia defeat its major enemy, poverty, just as the Ethiopian Empire defeated the Kingdom of Italy in Adwa in 1896 (Ethiopian Embassy in London, 2015). Likewise, Semegnew Bekele, the project manager of the GERD who in 2015 was elected Tigrai Online person of the year (Tigrai Online, 2016), stated that the GERD, like Adwa, will represent the determination of the Ethiopian people for future generations (Addis Fortune, 2013).

What is missing in these accounts is a discussion on the environmental, societal or economic impacts of the GERD, something that has never been mentioned despite the significant coverage 
devoted to the dam. Through a strategy arguably aimed at frustrating political action and avoiding protests, these issues have been removed from the political discourse and are only mentioned by opposition websites based abroad, such as Ethiomedia.com or Ecadforum.com. Ethiopian based journalists who criticised the project have been silenced. This was for instance the case of Reeyot Alemu, who in 2011 was accused of terrorism and arrested for having questioned Zenawi's fundraising methods for the GERD (IWMF, 2015). The ruling elite has prevented alternative representations of water and energy use in Ethiopia from even entering the domestic political debate.

As the dissident Ethiopian journalist Eskinder Nega illustrated, Zenawi frantically promoted the GERD "to deflect attention from sporadic but persistent calls for democracy [as] he still romanticizes a world which broadly tolerates repression" (Nega, 2011). Alemayehu G. Mariam, an Ethiopian academic based in the United States, tellingly explains that whenever he asked commonsensical questions about the economic feasibility of the GERD, he was swamped by online comments accusing him of "treason against Ethiopia by siding with Egypt [since he] should have been a lot more careful before writing an article that ... demonize the Ethiopian Government and devalue Ethiopia's sovereignty on its own rivers" (Mariam, 2015). And indeed, if one for example looks at the comments generated by any post on the GERD published in the Facebook pages of the Ethiopia's Ministry of Foreign Affairs or of Dr Tedros Adhanom, the tones are rather exacerbated and often pull into the discussion Egypt and matters related to the assertion of national pride. As a taxi driver in Addis Ababa effectively captured, "energy is important, Ethiopia needs energy, I need energy, but Egypt doesn't want us to get energy".

The rhetorical discourse emanated by the Ethiopian leadership is thus reproduced by its same recipients, who seem to perceive the GERD primarily as an assertion of sovereignty in a polarised geopolitical arena dominated by the rivalry with Egypt. Even though the GERD is still under construction, its physical space (and impact) has been concealed and transformed into a political one created by the action and speech of those inhabiting the public space of appearance. The spatial extent of the Ethiopian hydropolis is defined by the power dynamics currently at play in the Nile River Basin, which find a nodal point in the issue of large-scale hydraulic development. In Arendtian terms, the GERD provides an example of how the permanent change produced by human work can create new political spaces and reconfigure the ways in which we negotiate and imagine the extent of our space of appearance. At present, this seemingly borderless arena of political encounter springs up from the binary dialectic based on the distinction between an imagined Ethiopian nation and its rival, Egypt. However, hydropolitics, or the geopolitics of river basins, are constantly shifting under the influence of different forces and needs (Hirsch, 2016). Thus, and in light of the rapidly evolving hydropolitical scenarios in the Nile River Basin evidenced by the near completion of the GERD, the nature and extent of the hydropolis are likely to change in the future along with the inevitable change in the power relations therein. 


\section{CONCLUSIONS}

This paper has reinterpreted Arendt's (1958) conception of the polis to introduce the notion of the hydropolis. This served to shed light on the ways in which the Ethiopian leadership has transformed the physical space occupied by a large dam into a highly polarised geopolitical one. Based on its geopolitical perceptions on the Nile River, the Ethiopian elite has discursively constructed the GERD as a geopolitical object grounded on the friend/enemy distinction and on their rivalry with Egypt. Throughout the top-down imposition of a specific narrative, the space occupied by the hydropolis emerges as a seemingly borderless arena of political encounter configured around historical recriminations and the necessity, for those in power, to get legitimation and gain popular support.

While, on the one hand, Elden (2000) observed that modern technology offered new ways to resolve a friend/enemy problem in the $20^{\text {th }}$ century, on the other hand, it also seems to offer new means to nourish such issues in the $21^{\text {st }}$ century. The Internet and social media have indeed been instrumental in the framing of the GERD and in reaching out to the large Ethiopian diaspora.

Aside from the GERD, other large scale hydraulic infrastructures are at present causing several geopolitical conflicts globally. Examples include the large Xayaburi Dam on the Lower Mekong River, the Rogun Dam on the Vakhsh River, and the Myitsone Dam on the Irawaddy River. A critical approach that problematizes the notion of the political can improve our understanding of these conflicts and of the power dynamics behind them. The significant economic, environmental, and societal impacts of a large dam tend to be concealed by a thick layer of discourses created by their promoters. While Arendt's formulation of the polis leaves little room for a discussion on the materiality of water (refer to Lavau, 2013; Grundy-Warr et al., 2015; Steinberg and Peters, 2015), the 'more-than-human' is deeply enmeshed with dam development (as Mitchell [2002] tellingly illustrated in the case of the proliferation of the anopheles mosquito following the construction of the Aswan High Dam), and further studies should explore their interplay. Indeed, water, just like the space of appearance, is transient, mutable, and does not respect boundaries, and thus plays a central role in the stretching of the hydropolis. And yet, while the material effects of these infrastructures need to be discussed and studied, their ideological dimension is also important and deserves attention.

Future research could build on the theoretical contributions of this study to examine how international rivers are constructed as political objects based on specific spatial assumptions. Further work could also examine how top-down nation-building processes are intertwined with the construction of large hydraulic infrastructures, and consequently, with transboundary water politics. More discussions in this direction might further enrich key debates in critical geopolitics and hydropolitics, bringing attention to discursive practices of othering and the rationale and justifications behind them. 


\section{REFERENCES}

Abbink, J. (2012). Dam controversies: contested governance and developmental discourse on the Ethiopian Omo River dam. Social Anthropology, 20, 125-144.

Abbink, J., \& Hagmann, T. (Eds.) (2013). Reconfiguring Ethiopia: The politics of authoritarian reform. Abingdon: Routledge.

Abdelhady, D., Aggestam, K., Andersson, D.-E., Beckman, O., Berndtsson, R., Palmgren, K. B., Madani, K., Ozkirimli, U., Persson, K. M., \& Pilesjö, P. (2015). The Nile and the Grand Ethiopian Renaissance Dam: Is there a meeting point between nationalism and hydrosolidarity? Journal of Contemporary Water Research \& Education, 155, 73-82.

Ackerman, J. W. (2011). Andreas Kalyvas. Democracy and the politics of the extraordinary: Max Weber, Carl Schmitt, and Hannah Arendt. Cambridge: Cambridge University Press, 2008. 326 pp. The Germanic Review: Literature, Culture, Theory, 86, 320-324.

Addis Fortune (2013). Like the Adwa victory, the Great Ethiopian Renaissance Dam (GERD) will be venerated for generations. Addis Fortune, 2013, 15.12.2013. http://addisfortune.net/columns/like-the-adwa-victory-the-great-ethiopian-renaissancedam-gerd-will-be-venerated-for-generations/. Accessed 07.06.2016.

Adhanom, T. (2014). The Nile is a symbol of cooperation and collaboration: Dr. Tedros Adhanom. Embassy of The Federal Democratic Republic of Ethiopia (FDRE), 02.04.2014.

http://www.ethiopianembassy.org.in/Nile_is_a_Symbol_of_Cooperation_and_Collaborati on.htm. Accessed 08.06.2015.

Agnew, J. (2016). The origins of critical geopolitics. In The Ashgate Research Companion to Critical Geopolitics (pp. 19-32). Abingdon: Routledge.

Agnew, J. A. (2003). Geopolitics: Re-visioning world politics. (2nd ed). London: Routledge.

Akhter, M. (2015). The hydropolitical Cold War: The Indus Waters Treaty and state formation in Pakistan. Political Geography, 46, 65-75.

Alatout, S. (2008). 'States' of scarcity: water, space, and identity politics in Israel, 1948 - 59. Environment and Planning D: Society and Space, 26, 959-982.

Allan, J. A. (2001). The Middle East water question: Hydropolitics and the global economy. London: I.B. Tauris.

Arendt, H. (1958). The human condition. Charles R. Walgreen Foundation lectures. Chicago: University of Chicago Press.

Arendt, H. (1996). Love and Saint Augustine. Chicago, London: The University of Chicago Press. 
Arendt, H. (2006). On revolution. New York: Penguin Books.

BBC (1998). Ethiopian prime minister calls for changes in Nile waters agreement. $B B C$ Summary of World Broadcasts, 10.04.1998.

BBC (2011a). Ethiopia is not Egypt's enemy - Prime Minister Meles. BBC Monitoring Africa - Political, 15.05.2011.

BBC (2011b). Construction of dam to beat poverty - Ethiopian premier. BBC Monitoring Africa - Political, 16.05.2011.

BBC (2012a). Programme summary of Ethiopian TV news 1700 gmt 29 May 12. BBC Monitoring Africa - Political, 29.05.2012.

BBC (2012b). Programme summary of Ethiopian TV news 1700 gmt 26 Jul 12. BBC Monitoring Africa - Political, 26.07.2012.

BBC (2013a). Ethiopians urged "to stand for their country" in row with Egypt. $B B C$ Monitoring Africa - Political, 12.06.2013.

BBC (2013b). Programme summary of Ethiopian TV news 1700 gmt 18 Jun 13. BBC Monitoring Africa - Political, 18.06.2013.

BBC (2013c). Ethiopia berates Egyptian leaders for using dam as "pretext". BBC Monitoring Africa - Political, 18.09.2013.

BBC (2014a). Ethiopian commanders vow to deal with "enemy provocations" on Nile dam. BBC Monitoring Africa - Political, 17.02.2014.

BBC (2014b). Programme summary of EBC TV news 1700 gmt 9 Dec 14. BBC Monitoring Africa - Political, 09.12.2014.

BBC (2015a). (Corr) Programme summary of EBC TV news 1700 gmt 3 Jun 15. BBC Monitoring Africa - Political, 04.06.2015.

BBC (2015b). Programme summary of EBC TV news 1700 gmt 16 Jun 15. BBC Monitoring Africa - Political, 16.06.2015.

BBC News (2016). Ethiopian forces 'killed 400 Oromo protesters': BBC News, 2016, http://www.bbc.co.uk/news/world-africa-36546917.

Beinin, J., \& Lockman, Z. (1998). Workers on the Nile: Nationalism, communism, Islam, and the Egyptian working class, 1882 - 1954. Cairo: The American University in Cairo Press. Biro, A. (2007). Water politics and the construction of scale. Studies in Political Economy, 930.

Bobbio, N. (1994). Destra e sinistra: Ragioni e significati di una distinzione politica. Saggine. Roma: Donzelli.

Bobbio, N., Matteucci, N., \& Pasquino, G. (2004). Dizionario di politica. Roma: L'Espresso. 
Brookings (2013). While Egypt struggles, Ethiopia builds over the Blue Nile: Controversies and the way forward. Mbaku, J,M; Deressa, T. T., 25.07.2013. https://www.brookings.edu/blog/up-front/2013/07/25/while-egypt-struggles-ethiopiabuilds-over-the-blue-nile-controversies-and-the-way-forward/. Accessed 15.06.2015.

Budds, J. and Hinojosa, L. (2012). Restructuring and rescaling water governance in mining contexts: The co-production of waterscapes in Peru. Water Alternatives, 5, 119-137.

Buzan, B., Wæver, O., \& Wilde, J. d. (1998). Security: A new framework for analysis / Barry Buzan, Ole Waver, Jaap de Wilde. Boulder, Colo., London: Lynne Rienner.

Cascão, A. E. (2009). Changing power relations in the Nile River Basin: Unilateralism vs. cooperation? Water Alternatives, 2, 245-268.

Chacko, E., \& Gebre, P. H. (2013). Leveraging the diaspora for development: lessons from Ethiopia. GeoJournal, 78, 495-505.

Chen, H., \& Swain, A. (2014). The Grand Ethiopian Renaissance Dam: Evaluating its sustainability standard and geopolitical significance. Energy Development Frontier, 3, $11-19$.

Dalby, S. (1990). American security discourse: the persistence of geopolitics. Political Geography Quarterly, 9, 171-188.

Dalby, S. (2010). Recontextualising violence, power and nature: The next twenty years of critical geopolitics? Political Geography, 29, 280-288.

Dalby, S., Toal, G., \& Routledge, P. (2006). The geopolitics reader. (2nd ed). London: Routledge.

Di Nunzio, M. (2015). What is the alternative? Youth, entrepreneurship and the developmental state in urban Ethiopia. Development and Change, 46, 1179-1200.

Diez, T. (2010). Europe's others and the return of geopolitics. Cambridge Review of International Affairs, 17, 319-335.

Elden, S. (2000). Rethinking the polis. Political Geography, 19, 407-422.

Ethiopian Embassy in London (2015). Ethiopian News: The monthly publication from the Ethiopian Embassy in London.

Feitelson, E., \& Fischhendler, I. (2009). Spaces of water governance: The case of Israel and its neighbors. Annals of the Association of American Geographers, 99, 728-745.

Flyvbjerg, B., \& Ansar, A. (2014). Ending the flood of megadams: The $\$ 20$ billion cost of the Itaipu Dam impaired Brazil's finances for three decades. The Wall Street Journal, 18.03.2014. 
http://www.wsj.com/articles/SB10001424052702304704504579430923019746140. Accessed 07.07.2016.

Gagliardone, I. (2014). New media and the developmental state in Ethiopia. African Affairs, $113,279-299$.

Gebreluel, G. (2014). Ethiopia's Grand Renaissance Dam: Ending Africa's oldest geopolitical rivalry? The Washington Quarterly, 37, 25-37.

Giglioli, I., \& Swyngedouw, E. (2008). Let's drink to the great thirst! Water and the politics of fractured techno-natures in Sicily. International Journal of Urban and Regional Research, 32, 392-414.

Gramsci, A. (1975). Quaderni del carcere. Nuova Universale Einaudi, N.S., 1,3. Torino: Einaudi.

Gregory, D. (1994). Geographical imaginations. Cambridge, MA, Oxford: Blackwell.

Grundy-Warr, C., Sithirith, M., \& Li, Y. M. (2015). Volumes, fluidity and flows: Rethinking the 'nature'of political geography. Political Geography, 45, 93-95.

Hammond, M. (2013). The Grand Ethiopian Renaissance Dam and the Blue Nile: Implications for transboundary water governance. Global Water Forum, 18.02.2013. http://www.globalwaterforum.org/2013/02/18/the-grand-ethiopian-renaissance-dam-andthe-blue-nile-implications-for-transboundary-water-governance/. Accessed 03.10.2014.

Harris, L. M., \& Alatout, S. (2010). Negotiating hydro-scales, forging states: Comparison of the upper Tigris/Euphrates and Jordan River Basins. Political Geography, 29, 148-156.

Harvey, D. (1999). Time-space compression and the postmodern condition. Modernity: Critical Concepts, 4, 98-118.

Herodotus (1920). Herodotus: With an English translation by A. D. Godley. Cambridge: Harvard University Press.

Hirsch, P. (2016). The shifting regional geopolitics of Mekong dams. Political Geography, $51,63-74$.

Ibrahim, A. M. (2011). The Nile Basin cooperative framework agreement: The beginning of the end of Egyptian hydro-political hegemony. Missouri Environmental Law and Policy Review (MELPR), 18.

International Panel of Experts (IPoE) (2013). Grand Ethiopian Renaissance Dam: Final report. Addis Ababa.

International Rivers (2014). The Grand Ethiopian Renaissance Dam fact sheet. International Rivers, 24.01.2014. https://www.internationalrivers.org/resources/the-grand-ethiopianrenaissance-dam-fact-sheet-8213. Accessed 18.05.2015. 
International Women's Media Foundation (IWMF) (2015). IWMF courage winner and Ethiopian journalist Reeyot Alemu released from prison. International Women's Media Foundation (IWMF), 10.07.2015. https://www.iwmf.org/blog/2015/07/10/iwmf-couragewinner-and-ethiopian-journalist-reeyot-alemu-released-from-prison/. Accessed 17.10.2015.

Jima, Z. M. (2016). The Grand Ethiopian Renaissance Dam: A game-changer for Nile hydropolitics. The Official Blog of MFA Ethiopia, 13.06.2016.

https://mfaethiopiablog.wordpress.com/2016/06/13/the-grand-ethiopian-renaissance-dama-game-changer-for-nile-hydro-politics/. Accessed 14.06.2016.

Kaika, M. (2006). Dams as symbols of modernization: The urbanization of nature between geographical imagination and materiality. Annals of the Association of American Geographers, 96, 276-301.

Kalyvas, A. (2008). Democracy and the politics of the extraordinary: Max Weber, Carl Schmitt, and Hannah Arendt. Cambridge, New York: Cambridge University Press.

Kendie, D. (1999). Egypt and the hydro-politics of the Blue Nile River. Northeast African Studies, 6, 141-169.

Krishna, R. (1988). The legal regime of the Nile River Basin. In The politics of scarcity: water in the Middle East (p. 23-41). London: Westview Press.

Kuus, M. (2010). Critical geopolitics. In The International studies encyclopedia. Volume II (p. 683-701). London: Blackwell.

Lavau, S. (2013). Going with the flow: sustainable water management as ontological cleaving. Environment and Planning D: Society and Space, 31, 416-433.

Lentz, C. (2013). Celebrating independence jubilees and the millennium: national days in Africa. Nations and Nationalism, 19, 208-216.

Lyons, T., Ege, H. S., Aspen, B. T., \& Shiferaw, B. (2007). The Ethiopian diaspora and homeland conflict. Power, 44, 215-231.

Mariam, A. G. (2015). Ethiopia: The dam dammed by cash flow? Ecadforum.com, 30.03.2015. http://ecadforum.com/2015/03/30/ethiopia-the-dam-dammed-by-cash-flow/. Accessed 06.09.2015.

Mekonnen, D. Z. (2010). The Nile Basin cooperative framework agreement negotiations and the adoption of a 'Water Security'paradigm: Flight into obscurity or a logical cul-de-sac? European Journal of International Law, 21, 421-440.

Menga, F. (2015). Building a nation through a dam: the case of Rogun in Tajikistan. Nationalities Papers, 43, 479-494. 
Menga, F. (2016a). Reconceptualizing hegemony: the circle of hydro-hegemony. Water Policy, 18, 401-418.

Menga, F. (2016b). Domestic and international dimensions of transboundary water politics. Water Alternatives, 9, 704-723.

Menga, F., \& Mirumachi, N. (2016). Fostering Tajik hydraulic development: examining the role of soft power in the case of the Rogun dam. Water Alternatives, 9, 373-388.

Mirumachi, N. (2015). Transboundary water politics in the developing world. Earthscan studies in water resource management. London: Earthscan.

Mitchell, T. (2002). Rule of experts: Egypt, techno-politics, modernity. (4th pr). Berkeley, Calif.: University of California Press.

Mollinga, P. P. (2008). Water, politics and development: Framing a political sociology of water resources management. Water Alternatives, 1, 7-23.

Müller, M. (2008). Reconsidering the concept of discourse for the field of critical geopolitics: Towards discourse as language and practice. Political Geography, 27, 322-338.

Mustafa, D. (2007). Social construction of hydropolitics: The geographical scales of water and security in the Indus Basin. Geographical Review, 97, 484-501.

Nega, E. (2011). Meles Zenawi's threat against opposition parties. Ethiomedia.com, 08.04.2011. http://www.ethiomedia.com/above/2378.html. Accessed 07.04.2015.

Neufeld, M. A. (1995). The restructuring of international relations theory. Cambridge studies in international relations, 43. Cambridge, New York, NY: Cambridge University Press.

Norman, E. S., Cook, C., \& Cohen, A. (2016). Negotiating water governance: Why the politics of scale matter. Ashgate studies in environmental policy and practice. London: Ashgate.

Ó Tuathail, G. (2010). Localizing geopolitics: Disaggregating violence and return in conflict regions. Political Geography, 29, 256-265.

Ó Tuathail, G., \& Agnew, J. (1992). Geopolitics and discourse. Political Geography, 11, 190-204.

Orlowska, I. (2013). Forging a nation: the Ethiopian millennium celebration and the multiethnic state. Nations and Nationalism, 19, 296-316.

Pearce, F. (2015). On the river Nile, a move to avert a conflict over water. Environment 360, 12.03.2015.

http://e360.yale.edu/feature/on_the_river_nile_a_move_to_avert_a_conflict_over_water/2 855/. Accessed 07.01.2016. 
Pinkerton, A., Young, S., \& Dodds, K. (2011). Weapons of mass communication: The securitization of social networking sites. Political Geography, 30, 115-117.

Reuters (2011). Ethiopia 2011/12 budget boosts development spending, 05.07.2011. http://www.reuters.com/article/ozabs-ethiopia-budget-idAFJOE7640GO20110705. Accessed 20.05.2012.

Said, E. W. (1979). Orientalism. Vintage book. New York: Random House.

Said, E. W. (2000). Invention, memory and place. Critical Inquiry, 26, 175-192.

Salini Impregilo (No date). Grand Ethiopian Renaissance Dam project. http://www.saliniimpregilo.com/en/projects/in-progress/dams-hydroelectric-plants-hydraulic-works/grandethiopian-renaissance-dam-project.html. Accessed 07.06.2016.

Salman, S. M. (2013). The Nile Basin Cooperative Framework Agreement: a peacefully unfolding African spring? Water International, 38, 17-29.

Schmitt, C. (2007). The concept of the political. (Expanded ed). Chicago: University of Chicago Press.

Smith, S. E., \& AI-Rawahy, H. M. (1990). The Blue Nile: Potential for conflict and alternatives for meeting future demands. Water International, 15, 217-222.

Sneddon, C., \& Fox, C. (2006). Rethinking transboundary waters: A critical hydropolitics of the Mekong basin. Political Geography, 25, 181-202.

Sneddon, C., \& Fox, C. (2016). A Genealogy of the basin: scalar politics and identity in the Mekong River Basin. In Negotiating water governance: Why the politics of scale matter (pp. 41-58). London: Routledge.

Starr, J. R. (1991). Water wars. Foreign Policy, 82, 17-36.

Steinberg, P., \& Peters, K. (2015). Wet ontologies, fluid spaces: Giving depth to volume through oceanic thinking. Environment and Planning D: Society and Space, 33, 247-264.

Swain, A. (2002). The Nile River Basin Initiative: Too many cooks, too little broth. SAIS Review, 22, 293-308.

Swyngedouw, E. (1999). Modernity and hybridity: Nature, regeneracionismo, and the production of the Spanish waterscape, 1890-1930. Annals of the Association of American Geographers, 89, 443-465.

Swyngedouw, E. (2004a). Social power and the urbanization of water: Flows of power. Oxford geographical and environmental studies. Oxford, New York: Oxford University Press.

Swyngedouw, E. (2004b). Globalisation or 'glocalisation'? Networks, territories and rescaling. Cambridge Review of International Affairs, 17, 25-48. 
Swyngedouw, E. (2013). UN Water Report 2012: Depoliticizing water. Development and change, 44, 823-835.

Swyngedouw, E. (2014). Where is the political? Insurgent mobilisations and the incipient "return of the political". Space and Polity, 18(2), 122-136.

Tavani, E. (2013). Hannah Arendt: Aesthetics and politics of appearance. Proceedings of the European Society for Aesthetics, 5, 466-475.

Tawfik, R. (2016). The Grand Ethiopian Renaissance Dam: a benefit-sharing project in the Eastern Nile? Water International, 41, 574-592.

Tigrai Online (2013). Egyptian politicians caught plotting how to attack Grand Ethiopian Renaissance Dam. Tigrai Online, 04.06.2013. http://www.tigraionline.com/articles/egyptplan-attack-gerd.html. Accessed 05.08.2016.

Tigrai Online (2016). Tigrai Online person of the year 2015 is Engineer Simegnew Bekele. Tigrai Online, 02.01.2016. http://www.tigraionline.com/articles/tol-person-of-2015.html. Accessed 06.08.2016.

Tvedt, T. (2004). The River Nile in the age of the British: Political ecology and the quest for economic power. London: IB Tauris.

van Dijk, T. A. (2006). Ideology and discourse analysis. Journal of Political Ideologies, 11, $115-140$.

Vasunia, P. (2001). The gift of the Nile: Hellenizing Egypt from Aeschylus to Alexander. Classics and contemporary thought, 8. Berkeley: University of California Press.

Verhoeven, H. (2015). Africa's next hegemon: Behind Ethiopia's power plays. Foreign Affairs, 12.04.2015. https://www.foreignaffairs.com/articles/ethiopia/2015-04-12/africasnext-hegemon. Accessed 07.02.2016.

Walta Information Centre (2014). Egypt on GERD ‘smear campaign'. Walta Information Centre, 25.03.2014. http://www.waltainfo.com/index.php/news/detail/2921. Accessed 01.05.2015.

Warner, J. (2012). The struggle over Turkey's Ilısu Dam: domestic and international security linkages. International Environmental Agreements: Politics, Law and Economics, 12, $231-250$.

Warner, J. F., \& Zeitoun, M. (2008). International relations theory and water do mix: A response to Furlong's troubled waters, hydro-hegemony and international water relations. Political Geography, 27, 802-810. 
Warner, J., \& Zawahri, N. (2012). Hegemony and asymmetry: multiple-chessboard games on transboundary rivers. International Environmental Agreements: Politics, Law and Economics, 12, 215-229.

Water International (2016). Special issue: The Grand Ethiopian Renaissance Dam: Legal, political and scientific challenges. Water International, 41.

Wegerich, K., \& Warner, J. (2010). The politics of water: A survey. London: Routledge.

World Bank Group (2015). Ethiopia poverty assessment 2014. Washington, DC: World Bank Group.

Worster, D. (1985). Rivers of empire: Water, aridity, and the growth of the American West. (1st ed). New York: Pantheon Books.

Yihdego, Z., Rieu-Clarke, A., \& Cascão, A. E. (2016). How has the Grand Ethiopian Renaissance Dam changed the legal, political, economic and scientific dynamics in the Nile Basin? Water International, 41, 503-511.

Zeitoun, M., \& Warner, J. (2006). Hydro-hegemony - a framework for analysis of transboundary water conflicts. Water Policy, 8, 435.

Zeitoun, M., Cascão, A. E., Warner, J., Mirumachi, N., Matthews, N., Menga, F., \& Farnum, R. (2016). Transboundary water interaction III: contest and compliance. International Environmental Agreements: Politics, Law and Economics.

Zeitoun, M., Mirumachi, N., \& Warner, J. (2011). Transboundary water interaction II: the influence of 'soft' power. International Environmental Agreements: Politics, Law and Economics, 11, 159-178.

Zenawi, M. (2011). Ethiopian PM Meles Zenawi speech on launching GERD (text and videos). Meleszenawi.com, 02.04.2011. http://www.meleszenawi.com/ethiopian-pmmeles-zenawi-speech-on-launching-gerd-text-and-videos/. Accessed 03.04.2013.

Zerilli, L. M. G (2005). Feminism and the abyss of freedom. Chicago: University of Chicago Press.

Zhang, Y., Erkyihum, S. T., \& Block, P. (2016). Filling the GERD: evaluating hydroclimatic variability and impoundment strategies for Blue Nile riparian countries. Water International, 41, 593-610.

\footnotetext{
${ }^{1}$ Derg is the short name for the 'Coordinating Committee of the Armed Forces, Police, and Territorial Army'.

${ }^{2}$ Polis is the transliteration of the Greek word $\pi$ ó $\lambda \iota \varsigma$, which defined the city-state, the dominant political unit in
} the ancient Greek world. 
${ }^{3}$ The content of this website was downloaded in full on March 27, 2015 and therefore the author can easily access it even though the website went offline a few weeks after this date, presumably in April 2015.

${ }^{4}$ Gramsci (1975) ascribed to this category the intellectuals organically tied with those in power, in contrast with the traditional intellectuals, who consider themselves autonomous and independent from the dominant social group.

${ }^{5}$ Due to a different calendar system Ethiopia celebrated the turn of the millennium in 2007. 